Reet Pius

\title{
THE ALTAR PULPIT IN ESTONIAN CHURCH INTERIORS
}

The function of the altar in Lutheran liturgy is connected to the Sacrament of the Eucharist. The Sacrament of the Last Supper symbolises the sharing of God and the altarpiece or altar decoration supported this with a picture on the same subject. The first altarpiece in Estonia to depict the Last Supper was donated to the Kihelkonna Church in 1591. Of the thirty-five known altars that date from the $16^{\text {th }}$ century to the first decade of the $18^{\text {th }}$ century, the Last Supper was the subject in twenty-one of them. ${ }^{1}$ In the late $17^{\text {th }}$ century, the Crucifixion of Christ started to dominate as the main theme for altars. ${ }^{2}$ Theologically, this communicated the message of salvation through faith. These two themes predominated in the altar design of Estonian churches until the end of the first quarter of the $19^{\text {th }}$ century. ${ }^{3}$

Alongside the seeming traditionalism or even still lifes in altar art, the change that occurred in the $18^{\text {th }}$ century, which resulted in greater attention being paid to the architectural design of the altar and small altarpiece that marked the Communion table has been ignored, or is totally lacking. During the final quarter of the $18^{\text {th }}$ century, altar pulpits

DOI: http://dx.doi.org/10.12697/BJAH.2014.7.03

Translation by Juta Ristsoo

1 Reet Rast, “Altar - jumala laud ja esindusobjekt”, Eesti kunsti ajalugu, 2, 1520-1770 (Tallinn: Eesti Kunstiakadeemia, 2005), 320.

2 Rast, "Altar - jumala laud ja esindusobjekt", 323.

3 New topics and the arrival of painting compositions is covered by Hanna Ingerpuu's research. Hanna Ingerpuu, 19. sajandi altarimaalid Järvamaa, Raplamaa, Pärnumaa ja Läänemaa luterlikes kirikutes, BA thesis (Tartu: University of Tartu, 2004; copy in the Department of Art History at the University of Tartu). 
Fig. 1. Altar pulpit designed by J. W. Krause, (TÜR, Best. 9, Nr. 23/3). 
(Kanzelaltar in German) appeared primarily in Livonian churches, but some examples from Estonia are also known to exist.

The genesis and meaning of the pulpit for Lutheran churches is explained by Peter Poscharsky's study. ${ }^{4}$ Hartmut Mai has written a monograph about the phenomenon of evangelical altar pulpits. ${ }^{5}$ Mai analyses the altar pulpit from aspects related to liturgy, art, iconology and territorial history. Jan Harasimowicz's articles about the construction Lutheran church in Europe ${ }^{6}$ during the $17^{\text {th }}$ and $18^{\text {th }}$ centuries help to draw parallels with Estonia. In the Nordic region, during her study of the apogees of sacral space, the Swedish art historian, Anna Nilsén, noticed the appearance of altar pulpits in church interiors in the mid$18^{\text {th }}$ century, and connected this to the spread of Pietism. ${ }^{7}$

In the context of Livonia, the topic has been covered by Paul Campe, an architect and scholar of Latvian and German art history, in his article on the furnishings of country churches ${ }^{8}$ in the Vidzeme region 9 . In Estonia, altar pulpits have been mentioned by Sten Karling, a Swedish-Estonian art historian, in the context of his research on the integration of a rear panel, which was formerly a separate altarpiece, into the altar pulpit (1777). ${ }^{10}$ Karling notes that, in Estonia, the altar pulpit is a phenomenon dating back to the second half of the $18^{\text {th }}$ century and therefore is outside his area of interest. Krista Kodres's chapter on church interiors in Eesti kunsti ajalugu (History of Estonian Art) provides a survey starting with the earliest pulpits in Estonia and ending with the last examples of the

4 Peter Poscharsky, Die Kanzel: Erscheinungsform im Protestantismus bis zum Ende des Barock (Gütersloh: Verlagshaus G. Mohn, 1963).

5 Hartmuth Mai, Der evangelische kantzelaltar. Gesichte und Bedeutung (Halle (Saale): M. Niemeyer, 1969); Hartmut Mai, “Tradition und Innovation im protestantischen Kirchenbau bis zum Ende des Barock”, Geschichte des protestantischen Kirchenbaues/ Festschrift für Peter Poscharsky zum 60. Geburtstag, hrsg. von Klaus Raschzok, Reiner Sörries (Erlangen: Junge \& Sohn, 1994).

6 Jan Harasimowicz, "Protestantischer Kirchenbau im Europa des 17. und 18. Jahrhunderts", Religion und Kultur im Europa des 17. und 18. Jahrhunderts, Mainzer Studien zur Neueren Geschichte, 12, hrsg. von Peter Claus Hartmann (Frankfurt am Main: Peter Lang Europäischer Verlag der Wissenschaften, 2006), 327-370; Jan Harasimowicz, "Lutheran Churches in Poland", Lutheran Churches in Early Modern Europe, ed. by Andrew Spicer (Ashgate, 2012), 403-444.

7 Anna Nilsén, Focal Point of the Sacred Space. The Boundary between Chancel and Nave in Swedish Rural Churches: From Romanesque to Neo-Gothic, Acta Universitatis Upsaliensis: Figura Nova Series, 30 (Uppsala: Uppsala Universitet, 2003), 119-120, 253.

8 Paul Campe, Innenausstattung der Landkirchen im lettischen Distrikt von Vidzeme (Livland) im 17. und Jahrhundert, Commentationes balticae, vol. 6/7, 1 (Bonn: Baltisches Forschungsinstitut, 1959), 39.

9 Vidzeme generally coincides with Southern Livonia, or the Latvian-speaking area of Livonia. Since Livonia was one province, many phenomena must be dealt with across the language boundary. 10 Sten Karling, Holzschnitzerei und Tischlerkunt derRenaissance und des Barocks in Estland (Tartu: Õpetatud Eesti Selts, 1943), 50. 
Baroque style at the end of the $18^{\text {th }}$ century. ${ }^{11}$ In the churches from the Age of Enlightenment, space and form were coordinated, and Kodres has analysed the manifestations of Leonhard Christoph Sturm's ideas in local church architecture. ${ }^{12}$

The most complete survey of the stylistic development of churches in Livonia during the Age of Enlightenment is provided by Latvian art historian Ojārs Spārītis, ${ }^{13}$ who, in his book, also makes a short digression into Estonia, because Riga architect Christoph Haberland was involved in the construction of Classicist churches in Livonia. ${ }^{14}$ Haberland designed the St. John's Church in Valga and his style is discernible in the layout of Catherine's Church in Võru. ${ }^{15}$ In his treatment of the Valga church, Heinz Pirang, who was the first to deal with Haberland's work more thoroughly, refers to the altar pulpit as an innovation introduced by Haberland into local Classicist church interiors. ${ }^{16}$ Johann Wilhelm Krause often depicted altar pulpits in church interiors, which Spārītis attributes to the architect's Herrnhuter background. ${ }^{17}$

The voluminous encyclopaedia on Lutheran churches compiled by Vitolds Mašnovskis ${ }^{18}$ helps in orientating in the Lutheran church archi-

11 Krista Kodres, "Kirikusisustus”, Eesti kunsti ajalugu, 2, 342-361.

12 Krista Kodres, "Pühakoda kui tempel ja korrastatud struktuur. A.W.Hupel arhitektuurihindajana”, Kunstiteaduslikke Uurimusi, 17 (1-2) (2008), 39-51.

13 Ojārs Spārītis, "Klassizismus in der Sakralbaukunst Livlands", Klassizismus im Baltikum. Neun Beiträge zum 5. Baltischen Seminar 1993 (Lüneburg: Verlag Carl-Schirren-Gesellschaft, 2008), 53-104.

14 The liturgical necessity to ensure everyone equal opportunities to participate in services resulted in the development of a new spatial form already in the $17^{\text {th }}$ century, and ning Swedish architects also introduced the new style of Lutheran churches into Estonia. The centralised church with a central dome in Narva was built based on the plans of Swedish architect Erik Dahlberg. The Kaarli Church on Tõnismägi in Tallinn, which was built in 1670, was also shaped like a Greek cross. These buildings were destroyed in the Great Northern War. See Krista Kodres, "Kirikuarhitektuur Eestis 16. - 18. sajandil", Eesti kunsti ajalugu, 2, 310-311.

15 Paul Campe, Lexikon liv- und kurländischer Baumeister, Bauhandwerker und Baugestalter von 1400-1850, 1-2 (Stockholm: Humanistiska Fonden, 1951-1957), 324; Юрий М. Васильев, Классицизм в архитектуре Риги : очерк истории планировки и застройки Риги в конце ХVIII - начале ХІХ в. (Рига: Академия Наук Латвийской ССР, 1961), 151.

16 Heinz Pirang, "Christoph Haberland”, Jahrbuch für den Bildenden Kunst in den Ostseeprovinzen. IV Jahrgang (Riga: Architektenverein, 1910), 11.

17 Ojārs Spārītis, "Kirchenbau - vom Rigaer Dom bus zum Jungfernhof”, Johann Wilhelm Krause, Arhitektina Liivimaal: kataloog, 2, eds. Juhan Maiste, Kadi Polli, Mariann Raisma (Tallinn: Eesti Keele Sihtasutus, 2003), 239, 241.

18 Vitolds Mašnovskis, Latvijas luterāņu baznīcas: vēsture, arhitektūra, māksla un memoriālā kultūra : enciklopēdija četros sējumos = The Lutheran Churches of Latvia: history, architecture, art and memorial culture (Riga: SIA Due, 2005-2007). 
tecture of Latvia, as do the guidebooks on the houses of worship in Riga and Valmiera, which are intended for the public generally. ${ }^{19}$

An important rationalist author was Pastor August Wilhelm Hupel, whose Topographische Nachrichten ${ }^{20}$ is, on the one hand, scientific, and on the other, provides good source material. The drawings and comments of Hupel's contemporaries, Johann Christoph Brotze ${ }^{21}$ and Eduard Philipp Körber, ${ }^{22}$ supplement Hupel's observations.

In the $17^{\text {th }}$ century, the orthodox ecclesiastic policy of the Swedish state is characterised by intolerance for Lutheran sects. The Great Northern War (1700-1721) ended Swedish rule in Estonia and Livonia and the provinces were transferred to the Tsarist Russian state; the local religious life became extremely diverse, although Swedish ecclesiastical law remained in force until 1832. After the Great Northern War, pastors from Germany who were Pietists and Herrnhuters came to Estonia. Their attitude toward the peasants differed from their predecessors and they were more inclusively disposed toward them, which resulted in the Estonians and Latvians actually being Christianised. Many research papers about the activities of the Pietists and Hernnhuters have been published because they played a noteworthy role in the national awakening of the Estonians and Latvians. ${ }^{23} \mathrm{~A}$ very thorough monograph about the literature of the

19 Jānis Kalnačs, The Heritage of Religious Architecture and Art in Valmiera District (Rīga: Neputns, 2010); Marina Levina, Jānis Zilgalvis, Agrita Tipāne, Dace Čoldere, Vita Banga, The Heritage of Religious Architecture and Art in Riga (Riga: Neputns, 2010).

20 August Wilhelm Hupel, Topographische Nachrichten von Lief- und Ehstland, 1-3 (Riga: Johann Friedrich Hartknoch, 1774, 1777, 1782)

21 Johann Christoph Brotze, Estonica, eds. Ants Hein, Ivar Leimus, Raimo Pullat, Ants Viires (Tallinn: Estopol OÜ, 2006).

22 Eduard Philipp Körber's manuscripts are stored in the Estonian Learned Society's collection (hereinafter ÕES) of the Estonian Cultural History Archives of the Estonian Literary Museum (hereinafter EKLA): EKLA, ÕES, MB 52 (Der Livländischen Kirchen und Prediger-Nachrichten. Erste Thl., 2. Abth.) (1825).; EKLA, ÕES, MB 53 (Diarium biographicum Ministerii Ecclesiastici. Dioecoesium Dorpatensis \& Pernaviensis...); EKLA, ÕES, MB 54 (Denkwürdigkeiten der livländischen Kirche seit der Reformation derselben bis auf gegenwartige Zeiten in Chronologischen Tabellen) EKLA, ÕES, MB 1:6; EKLA, ÕES, MB 1:8 (Läti); EKLA, ÕES, MB 73 (Körber, E. P. Kirchen und Prediger Nachrichten von Livland in alphabetischer Ordnung der Kirchen. Zweyter Theil. Lettischer Distrikt); EKLA, ÕES, MB 1:9 (Tartu). The manuscripts are also available in the KIVIKE repository at https://kivike.kirmus. ee/index.php?dok_id=1\&module=2\&op= (viewed 21.08.2014).

23 Voldemar Ilja, Vennastekoguduse (herrnhutluse) ajalugu Eestimaal (Põhja-Eesti): 1730-1743 (Tallinn: Logos, 1995); Voldemar Ilja, Vennastekoguduse (herrnhutluse) ajalugu Liivimaal (LõunaEesti) 1729-1750, III (Tallinn: Logos 2002); Jaanus Plaat, Usulikumised, kirikud ja vabakogudused Lääne- ja Hiiumaal: usuühenduste muutumisprotsessid 18. sajandi keskpaigast kuni 20. sajandi lõpuni (Tartu: Eesti Rahva Muuseum ,2001); Mati Laur, "Vennastekogud - ajalooline side Tšehhimaaga", Horisont, 5 (1998), 30-31. 
Moravian Church based on research in the Herrnhuter's archives ${ }^{24}$ was published by Rudolf Põldmä ${ }^{25}$. The book also includes other interesting material on the activities of the Moravians more generally, which related is to cultural history. A more recent account of the Pietists and Moravians was published by Gvido Straube and Mati Laur. ${ }^{26}$

Based on our national self-perception, these accounts view the events from the viewpoint of the peasantry. But the nobility was also inspired by Herrnhutism and many influential noble families joined the movements, including the Campenhausens, Ungern-Sternbergs, Stackelbergs, Uexkülls, Tiesenhausens and Vietinghoffs. ${ }^{27}$ Anne Untera, in her study of the provenance of a painted portrait of Baroness Barbara Juliane von Krüdener has also alluded to her Herrnhutism-related religious activism. ${ }^{28}$ Barbara Sommer's monograph about Krüdener makes a detour into the religious salon culture cultivated by the Baltic nobility. ${ }^{29}$ According to church historian Riho Saard, the most recent idealistic thinking from Western Europe arrived in Livonia via the Herrnhutist nobility and their children's tutors. ${ }^{30}$ Nicholas Hope examines the church life in Livonia from a broader perspective, without needing to position himself based on nationality. ${ }^{31}$ Hope calls the boundary between the Pietists and Herrnhutists blurred if not non-existent, and one must agree. ${ }^{32}$

In 1743, the Herrnhut movement was banned, ${ }^{33}$ although after the tolerance manifesto issued by Catherine the Great in 1764, the Brothers were again allowed to come to Russia, which is why the Brothers in

24 Unitätsarchiv Herrnhut, see Mati Laur, “Täiendavalt Eesti ainestikust Herrnhuti arhiivis”, Kleio, (5-6), (1992), 77-78.

25 Rudolf Põldmäe, Vennastekoguduse kirjandus (Tartu: Ilmamaa 2011). The book was published 23 years after the author's death.

26 Gvido Straube, Mati Laur, "Der Hallische Pietismus und die Herrnhuter Brüdergemeine in Livund Estland im 18. Jahrhundert”, Forschungen zur baltischen Geschichte, 4, (2009), 97-114.

27 Riho Saard, Kristluse ajalugu selle algusest tänapäevani (Argo, 2013), 399.

28 Anne Untera, "Viitina mõisaproua Barbara Juliane von Krüdeneri portree lugu", Kunstiteaduslikke Uurimusi, 21 (1-2) (2012), 247-260; is a new approach, which examines the development of a metropolitan Baltic noblewoman into a promoter of the Hernnhuter movement, who also spread her ideas to crowned heads.

29 Debora Sommer, Eine baltisch-adlige Missionarin bewegt Europa: Barbara Juliane v. Krüdener, geb. v. Vietinghoff gen. Scheel (1764-1824) (Göttingen: V \& R Unipress, 2013).

30 Saard, Kristluse ajalugu selle algusest tänapäevani, 399.

31 Nicholas Hope, German and Scandinavian Protestantism 1700-1918 (Oxford University Press, 1999). In the $18^{\text {th }}$ century Swedish church law continued to apply in Estonia and Livonia although most of the pastors came from Germany and had been educated at German universities.

32 Hope, German and Scandinavian Protestantism 1700-1918, 248.

33 Andres Andresen, Eestimaa kirikukorraldus 1710-1832. Riigivõimu mõju institutsioonidele ja õigusele. PhD thesis (Tartu: Tartu Ülikooli kirjastus, 2004), 134. 
Estonia and Livonia concluded that they had the same rights. ${ }^{34}$ The Rationalist movement ${ }^{35}$, which arrived via the pastors who came from foreign universities, was opposed to the "kind-heartedness" of Pietism and Herrnhutism, but it was well-meaning towards them. ${ }^{36}$ By the last quarter of the century, Rationalism had spread to the point that Christian David Lenz, the General Superintendent of Livonia, who defended Lutheran orthodoxy, had to agree to the old songbook being replaced by a new, Rationalist one. ${ }^{37}$ Rationalism flourished when the University of Tartu was reopened in 1802 . The university faculty members were Rationalists, with only one exception, and thus the education of future pastors took place in the spirit of Rationalism. ${ }^{38}$ Theological diversity may be summarised by the idea that not only Rationalists, but also Pietists and Herrnhutists were enligtheners in $18^{\text {th }}$ century Livonia, because their goal was to improve society.

The responsibility for renovating or rebuilding the churches fell to two superior church wardens (Oberkirchenvorsteher in German), ${ }^{39}$ who were chosen by the manor lords from among their peers for three years. ${ }^{40}$ The educational backgrounds, social circles and worldviews of the pastors definitely affected church construction, although the experiences and aesthetic preferences of the responsible superior church warden were more even more decisive.

\section{ALTAR PULPITS}

The very first altar pulpit was built in the Hartenfels castle in Torgau in $1544,{ }^{41}$ although their construction in the German cultural space

\footnotetext{
34 Olaf Sild, Vello Salo, Lühike Eesti kirikulugu (Tartu: 1995), 103.

35 Sild, Salo, Lühike Eesti kirikulugu, 104, 105. The Rationalist movement viewed church life from a standpoint of common sense and "natural" morality, the natural sciences and the state. The fundamental concepts were the virtue and immortaligy of God. In addition to ecclesiastic activities, the Rationalists also dealt with the improvement of schools and literature, as well as the economic and social life of the people.

36 Indrek Jürjo, Liivimaa valgustaja August Wilhelm Hupel 1737-1819 (Tallinn: Riigiarhiiv, 2004), 263.

37 Sild, Salo, Lühike Eesti kirikulugu, 104; Christian August Berkholz, Zur Gesichte des Rigaischen Gesangbuches (Riga: Druck von W. F. Häcker, 1878), 33-41.

38 Sild, Salo, Lühike Eesti kirikulugu, 104-105.

39 Andresen, Eestimaa kirikukorraldus 1710-1832, 147.

40 Andresen, Eestimaa kirikukorraldus 1710-1832, 121, 122. In Livonia, rural councillors who belong to the upper level of the hierarchy were chosen as superior church wardens.

41 Mai, Der evangelische kantzelaltar, 15.
} 
reached their zenith in the $17^{\text {th }}$ century ${ }^{42}$ In his book titled KirchenGebäw published in 1649, the Ulm city architect, Joseph von Furttenbach, recommended that the altar, pulpit and organ in Protestant churches be placed above one another. ${ }^{43}$

Harmut Mai, the most famous researcher of altar pulpits, divides them into two large categories based on their construction. In the first, the pulpit is separate from the altar, and in the second, the pulpit is closely tied to the design of the altar. These two categories are further divided into subtypes. The altars in Estonia-Livonia belong to the second category, which has five subtypes. In the $17^{\text {th }}$ century, the wing-altar, which was beloved in the German cultural space, was revived as the wing-altar pulpit. ${ }^{44}$ The second subtype is the altar pulpit with pictures, with the pulpit being located behind the picture. Other subtypes include ornamented altars and those categorised by distinctive regional differences. Harmut Mai places architectonical or porticoed altar pulpits into the fifth group. ${ }^{45}$ These altars have two or more columns and resemble antique porticos, with the pulpit located between the columns. The columns are crowned with acoustic eaves, which connect the columns on either side of the structure into an integrated whole and which visually resemble the portico of a temple. These porticoed altar pulpits can have one or two stories. The first porticoed altar pulpits were installed in the early $18^{\text {th }}$ century in the castle chapel in Zerbst (Anhalt) (destroyed in World War II) and the church in Pößneck Jüdeweini (Thüringen) (destroyed). ${ }^{46}$ The Lutheran Church is a preaching-church. It was recommended that altar pulpits be installed for practical purposes in small village churches in order to use the space more rationally, ${ }^{47}$ although in the second half of the $18^{\text {th }}$ century, saving space becomes less of a reason for installing altar pulpits, and the beauty of the churches becomes the primary one. ${ }^{48}$

\footnotetext{
42 Ibid.,16.

43 Joseph Furttenbach, Kirchengebäw (Augsburg: Johann Schultes, 1649).

http://reader.digitale-sammlungen.de/de/fs1/object/display/bsb10048335_00023.html?zoom=0.55 (viewed 21.08.2014)

44 Mai, Der evangelische kantzelaltar, 17.

45 Ibid., 19.

46 Ibid.. 19; http://www.schloss-zerbst-ev.de/html/geschichte_e.htm (viewed 21.08.2014)

47 Mai, Der evangelische kantzelaltar, 76, 78.

48 Ibid., 77.
} 


\section{LEONHARD CHRISTOPH STURM'S TEMPLES OF THE HOLY SPIRIT AND MARC-ANTOINE LAUGIER'S AESTHETICS}

German mathematician and architectural theoretician Leonhard Christoph Sturm was a Pietist, ${ }^{49}$ and thus in his books he calls churches the Temples of the Holy Spirit (in German Tempel des Heiligen Geistes). God is the Holy Spirit and by building churches, one is erecting temples to the Holy Spirit. The model for the Temples of the Holy Spirit is provided by the Bible; Solomon's building of the Temple is the main motif in the development of pietist architecture..$^{50}$ The Pietists sought a direct connection to the first congregation and the primary sources, ${ }^{51}$ and this is apparent in church construction. Sturm believed that the beauty of the heart's temple was inversely proportionate to the exterior splendour of a church building. ${ }^{52}$

Architectonisches Bedencken von Protestantischer kleinen Kirchen Figur und Einrichtung 53 printed in Hamburg in 1712 and Vollständige Anweisung, alle Arten von Kirchen wohl anzugehen, ${ }^{54}$ which appeared six years later, became the handbooks for church construction in the German cultural space. ${ }^{55}$ In the former, Sturm proposes a church with a circular floor

49 Mai, Der evalgelische kantzelaltar, 74. The foundation for Pietism, which developed in the late $17^{\text {th }}$ century, was laid by Philipp Jakob Spener with his programmatic work Pia desideria (Pious Desires). See Philipp Jacob Spener, Pia desideria: Programm des Pietismus, in neuer Bearbeitung herausgegeben von Erich Beyreuther (Wuppertal: Aussaat, 1964). Spener believed that a rebirth of the Lutheran Church was necessary, which should be based on deep piety. The external expression of this idea was a new direction at meeting, where the Bible was read, spiritual songs were song and "pious exercises" conducted. Spener planned to explore all the existing Biblical texts, and he recommended that theologian read the Bible in the original languages.

50 Hanno-Walter Kruft, A history of Architectural Theory from Vitruvius to the present (London: Zwemmer; New York: Princeton Architectural Press, 2007), 176-177.

51 Toomas Paul, Eesti piiblitõlke ajalugu: esimestest katsetest kuni 1999. aastani (Tallinn: Emakeele Selts, 1999), 267.

52 Mai, Der evangelische kantzelaltar, 74.

53 Leonhard Christoph Sturm, Architectonisches Bedencken von Protestantischer kleinen Kirchen Figur und Einrichtung: Mit dazu gehörigen Rissen (Hamburg: 1712).

http://reader.digitale-sammlungen.de/de/fs1/object/display/bsb10913306_00002.html (viewed 21.08.2014)

54 Leonhard Christoph Sturm, Vollständige Anweisung, alle Arten von Kirchen wohl anzugeben: worinnen 1. Nic. Goldmanns Anweisung und drey Exempel angeführet, und mit Anmerckungen erläutert. 2. Ausführlicher von Römisch-Catholischen Kirchen, und insonderheit 3. Von dem künstlichen Bau der grossen Kuppeln. 4. Von Protestantischen Kirchen gehandelt, mit fünff neuen Inventionen von jenen, und sechs von diesen der Praxi gemäss erkläret, und in 22. saubern Kupffer-Platten appliciret wird. (Augsburg: Verlegung Jeremiae Wolffens, 1718). Sturm deals with both Catholic (Roman Catholic) and Protestant church construction, without becoming trans-confessional.

55 Kruft, A History of Architectural Theory, 179. 
plan, the pews of which are placed in a semi-circle, like an amphitheatre, with the pulpit at the end of the central axis. ${ }^{56}$ The same layout is used for a church with a square floor plan, with the pews placed in a U-shape formation. ${ }^{57}$ In Sturm's plans for small churches, the pulpit and altar are combined for practical purposes, in order to use the space rationally.

Essai sur l architecture by French Catholic priest Marc Antoine Laugier was published in France in 1753 . The book quickly became very popular, was translated into English two years later ${ }^{58}$, and the German translation appeared in $1756 .^{59}$

Laugier appreciated the beauty of simple forms. ${ }^{60} \mathrm{He}$ thought that a simple hut made of tree trunks made an excellent elementary architectural element. ${ }^{61}$ A tree trunk is like a primeval column. According to Laugier, Grecian architecture was based on primeval elements, but the architecture was also beautiful since the Greek people were free. ${ }^{62}$ Sturm's circular and square floor plans designed for small churches would have conformed to Laugier's criteria for beauty. ${ }^{63}$ Light should be the most important element in a church, because it beautifies the space. In a well-proportioned space, light flows unimpeded. Laugier criticised the placement of the high altars in the middle of churches under their domes ${ }^{64}$ or in front of the choirs. In the first case, the altar divides the church in two, cuts off the light and prevents part of the congregation from observing the service. Laugier believed that an altar placed in front of the pulpit ${ }^{65}$ or choir barricades access to the choir. He rec-

\footnotetext{
56 Sturm, Architectonisches Bedenken, Tab, VI.

57 Sturm, Architectonisches Bedenken, Tab, II.

58 Hugh Honour, Neo-classicism (Harmondsworth: Penguin Books, 1968), 29; Dorothea Nyberg, "Laugier and the Eighteenth-Century French Theory by Wolfgang Hermann", The Art Bulletin 16 (1) (1964), 107.

59 Marc-Antoine Laugier, Versuch über die Baukunst (Frankfurt und Leipzig: 1756).

60 Marc-Antoine Laugier, An essay on architecture; in which its true principles are explained, and invariable rules proposed, for directing the judgment and forming the taste of the gentleman and the architect, with regard to the different kinds of building, the embellishment of cities (London: T. Osborne and Shipron In Gray Inn, 1755). Laugier sees simplicity and beauty in nature and therefore the column is a metaphor for a tree's beauty and in his approach to architecture, the column is a fundamental architectural concept. Laugieri believes that ornamentation destroys majestic simplicity. Kruft, $A$ History of Architectural Theory, 245.

61 Laugier, An Essay on Architecture, 11

62 Ibid., 3.

63 Mai, Der evangelische kantzelaltar, 75.

64 Laugier, An Essay on Architecture, 215.

65 Kodres, “Kirikusisustus”, 344. Laugier's examples are from Catholic churches; however in Lutheran churches the pulpit was located in the central nave, on a pillar or wall; in parish churches at the juncture of the nave and choir; in Estonia usually on the north side.
} 
ommended that the altar be placed at the bottom of the choir, where it would be visible to everyone ${ }^{66}$ and would emphasise the meaning of the altar, or in an alcove a few steps higher up. The decoration of the altar should be simple and majestic;, ${ }^{67}$ he recommends that marble and copper be used, and "a triangle with the Lord's name and flying angels" be placed in a prominent location in the architrave separating the two rows of columns. "[An] altar thus designed as I have described, would be a perfect beauty", 68 Laugier deprecates ornamentation and all kinds of "pedestals thrown here and there".

\section{ALTAR PULPITS IN ESTONIA}

As already mentioned, there were no changes in the subject matter depicted on altarpieces until the $19^{\text {th }}$ century. The iconic images of Pietism ${ }^{69}$ - "Ecce Homo" after Guido Reni, "the Good Shepherd" and "the Saviour Knocking at the Door" - do not appear in Estonian ecclesiastical art until the $19^{\text {th }}$ century. Paintings of "the Transfiguration of Christ" after Raphael, a typical work of the Age of Enlightenment ${ }^{70}$, also appeared in the churches in the $19^{\text {th }}$ century. ${ }^{71}$

Paul Campe demarcates the spread of altar pulpits in Livonia as occurring between the mid-18 ${ }^{\text {th }}$ century and the first quarter of the $19^{\text {th }}$ century. ${ }^{72}$ The altar pulpits were installed in new stone churches. There

66 Laugier, An Essay on Architecture, 217.

67 Ibid., 218.

68 Ibid., 220.

69 Hans Carl von Haebler, Das Bild in der evangelischen Kirche (Berlin: Evangelische

Verlagsanstalt, 1957), 68.

70 Heiki Hankka, Kirkkomaalauksen traditio ja muutos 1720-1880: Carl Frederik Blom murrosajan maalarina (Jyväskylä: Jyväskylän Yliopisto 1997), 102.

71 Two compositions painted after Raphael's The Transfiguration, which may date from the $18^{\text {th }}$ century, are known to exist in Estonia (see Tiina-Mall Kreem, "Maalikoopiad Eesti evangeelses luterlikus kirikus", Meistriteoste lummus. Koopia 19. Sajandi. Kadrioru kevadkonverents 2006 (Tallinn: Kadrioru kunstimuuseum, 2007), 52); Estonian Historical Archives (hereinafter EAA), 1196-2-28, 26; EAA, 1244-1-15, 95. The painting from the Kirbla (Läänemaa) church, called The Transfiguration of Christ was not donated to the church until 1840, before that the altar was decorated with the usual "Christ on the Cross". A similar painting in the Kodavere (historically in Tartumaa, currently in Jõgevamaa) church has been referred to as the "Resurrection" (in German Auferstehung) in literature, not as the "Transfiguration of Christ” (in German Verklärung).

72 Campe, Innenausstattung der Landkirchen, 38-39.

Campe considered the altars built in the Olaine and Lèdurga churches in 1753 and 1755 respectively to be the first altar pulpits. The Lèdurga church, where the altar is located was not built until 17671772. The installation of altar pulpits was discontinued in the 1820 s, but for financial reasons they remained in the churches until the end of the 1880 s. 
Fig. 2. Altar pulpit in the Tuhala Kaarli church. Photo by Ülle Jukk. 
were exceptions, according to Spārītis, a altar pulpit was installed in the wooden St. Gertude's Church in a suburb of Riga, which was one of Christoph Haberland's early works. ${ }^{73}$

The Great Northern War, after which the population in Estonia had declined to 170,000 people, left a deep imprint on church construction. The ravaged congregations did not have the strength or need to build new churches. However, by the end of the $18^{\text {th }}$ century, the population of Estonia had increased to half a million and the existing churches became overcrowded or the unmaintained wooden churches had become so dilapidated that new churches had to be built. However, typical of the Enlightenment, not just houses of worship, but beautiful churches had to be built. ${ }^{74}$

In comparison, the altar pulpit was not adopted in post-Reformation Sweden, but a change did take place in the second half of the $18^{\text {th }}$ century and this altar type remained in use until the 1830s, when it was prohibited. Altar pulpits were banned in Germany by the Dresden regulation of $1859 .^{75}$

The altar pulpit did not achieve the same popular in Estonia and Livonia as it did in Germany. In the Räpina church, the pulpit was initially at a "dizzying height" above the altar, then it was installed next to the altar and finally in its current location between the altar and the congregation's pews, to the left of the church's central axis. ${ }^{76}$ However, in several churches, the altar pulpits were not removed for a long time due to financial problems - the congregations did not have the money to rebuild them, because the altar walls, which were now empty, also needed repair. The purchase of a new altarpiece for the Räpina church in 1872 is immediately noted in the inventory lists, ${ }^{77}$ and a decade later, the congregation in Karksi is glad when the amount necessary for moving the pulpit has finally been collected. ${ }^{78}$

73 Spārītis, "Klassizismus", 74. St. Gertrude's Church is known only from drawings, because it was destroyed already in 1812 .

74 EAA, 1299-1-98, 1.

75 Nilsén, Focal Point of the Sacred Space, 252.

76 Anton Saarman, Pudemeid Räpina koguduse ajaloost: Räpina kiriku 150. aasta juubelipäevaks

(Räpina, Võru: V. Pohlak 1935), 9.

77 EAA, 1269-1-546, 23p.

78 TÜR, 55-3- 73, 25. 
An exception is the project for the Harju-Jaani church, which was completed in 1860, in which the pulpit is placed above the altar, but in the 1864 project, it is already crossed out. ${ }^{79}$

Paul Campe tallies up 13 altar pulpits in the Vidzeme region from the late $18^{\text {th }}$ century to the end of the first quarter of the $19^{\text {th }}$ century. ${ }^{80}$ In the Estonian areas, the altar pulpits in the Tuhala and Kassari churches have survived from that time. On the territory of former Livonia, there is archival information on altar pulpits in the Räpina and Karksi churches as well as in St. John's Church in Valga ${ }^{81}$; and art historian Kaur Alttoa believes there may have been one in Catherine's Church in Võru.

In Latvia, some altar pulpits still existed in the $20^{\text {th }}$ century. In the Liepupe church with its unusual floor plan, which was completed in 1782, the altar pulpit that was destroyed by a fire in 1971 was restored in the 1990s based on old photographs. ${ }^{82}$ An altar pulpit, with only its architectural form and without any pictures, is still in use today in the Reformed Church of Riga. ${ }^{83}$

The removal of the altar pulpits from the churches is one reason why they have not attracted the interest of researchers. This is also the reason for the complexity of the subject - obtaining an overview of the extent of the altar pulpits is complicated by the one-sidedness and scarcity of the informational sources.

The altar pulpit in Kaarli Church in Tuhala, ${ }^{84}$ which was completed in 1777 , has survived in its original form..$^{85}$ The chapel built in the Kose parish is representative of the concept of an economical church popular that time. The pulpit and altar are combined on the eastern wall of

79 Tiina-Mall Kreem, Viisipäraselt ehitatud. Luterlik kirikuehitus, -arhitektuur ja -kunst Eestis Aleksander II ajal (1855-1881), PhD thesis (Tallinn: Eesti Kunstiakadeemia, 2010), 118-119.

80 Campe, Innenausstattung der Landkirchen, 38.

81 EAA, 1299-1- 96, 1.

82 Spārītis, "Klassizismus", 83-84. The church plans have survived in the National Archives of Latvia: LVVA, 4287-1-1. The altar pulpit from the Liepupe church, which burned in 1971, was restored in the 1990s at the initiative of Ojārs Spārītis. The Liepupe church is exceptional because its tower and the main portal under the tower are located in the middle of the longer, southern wall of the church, and the altar pulpit is opposite the entrance along the wide northern wall. The pews were arranged perpendicularly in two groups along the wall and there is a choir installed as a peristyle. During the service, the pastor was always visible to the congregation. Liepupe is in the Salatsi region, which borders on Pärnu County.

83 Levina, The Heritage of Religious Architecture and Art in Riga, 104-111.

84 This church, commissioned by the lord of the local manor, Carl Johann von Mellin. The name chosen for it was selected in his honour.

85 The altar pulpit has survived in its initial form, but is now used as an altarpiece, i.e. altar decoration. A Communion table has been built in front of it and the pulpit is on the north side of the church. 
the nave. An earlier altarpiece titled Christ on the $\mathrm{Cross}^{86}$ is on the rear wall of the altar pulpit, while paintings from various eras are installed on the polygonal frame of the altar pulpit. One of the early paintings is Women at Christ's Tomb. On either side of it, we see painted panels, which date from the time that the church was built, with Rococo-style figures of angels in bright colours and another panel depicting Moses. Moses, who is usually depicted on altars along with John the Baptist, is a single figure here who expresses the principle of moral Christianity - the basis for the Enlightenment-era Church assuming the role of moral guardian.

Next, we will examine three architectonical altar pulpits based on Mai's classification that can be considered monuments to the elitist concept of art prevalent in the last quarter of the $18^{\text {th }}$ century.

\section{ALTAR PULPIT IN THE KARKSI CHURCH}

August Wilhlem Hupel calls the new stone church in Karksi one of the most captivating churches built after $1774,{ }^{87}$ that is, after the publication of part one of his Topographische Nachrichten.$^{88}$ Along with beauty of the church, Hupel praises the large sacristy and hopes that the Germans, who were obviously in the minority, but for whom services were conducted in German, would no longer have to freeze in the winter. According to the church chronicles, the church was not consecrated until 3 September 1778, and therefore, may not have been furnished during Hupel's visit. Hupel also praised the harmony of the Õisu manor house with the surrounding landscape. His detailed descriptions allow one to assume that he visited these places in person. The Karksi church creates an exalting cultural landscape, which has been portrayed by many artists. Hupel may have meant his assessment of "captivating" to apply to the church as whole, to the good sense of proportion, and harmony with its surroundings.

The Karksi church is a rectangular hallchurch, the main entrance of which is marked by a belfry that is narrower than the main body of the church. There is a large door below the tower, which is framed by pi-

86 Karling, Holzschnitzerei und Tischlerkunst, 50.

87 Hupel, Topographische Nachrichten 2, 71: „Seit 1774 ward am letzten Ort eine hübsche Kirche von Stein erbaut, und mit einer grossen Sakristey versehen, in welcher der deutsche Gottesdienst bey strenger Kälte kan gehalten werden."

88 Previously, there was a wooden church in Karksi. 
Fig. 3. August Matthias Hagen. Karksi Church. Oil, canvas, 1840 (AME).

lasters. ${ }^{89}$ The sacristy is on the end wall of the single-nave church. The pilasters from the portal are reproduced on the altar pulpit and are still in place today after being modified somewhat in the $19^{\text {th }}$ century. ${ }^{90}$ The capitals of the altar's columns and pilasters in the Corinthian style are similar to the description of the capitals of the Temple of Solomon: "the tops of the columns were shaped like blossoms". ${ }^{91}$ Above the columns, there are multistage entablatures and the altar is crowned by a Rococo-style curved frontispiece, with angels sitting on both edges of the volutes. The central section, above the capitals, is designed as clouds that connect the columns on either side. The heads of angels appear from the clouds, and in the middle, we see a triangle with the name of Christ in Hebrew. Thus, it corresponds to Laugier's dictate of "perfect

89 A round-arched frontispiece and pilasters are visible on the drawings of the Karksi castle ruins in Brotze's collection. Brotze, Estonica, 399.

90 University of Tartu Library (hereinafter TÜR), Rare book, manuscripts, photo and art collection (hereinafter KHO), 55-3-73, 25. (Salme Aarendi-Kokk. Karksi ew.- lut. Peetri kiriku tähtsamad mälestusmärgid. Manuscript. 1930) The altar is still located in the original location, but the pulpit that was located in the central section was replaced in 1884 with a picture called the Resurrection. The horizontal Last Supper is in its original location.

91 (1 Kings 7:22); According to Vitruvius's description the Solomonic column is decorated with Corinthian capital thought to have been used in the construction of Solomon's Temple. 


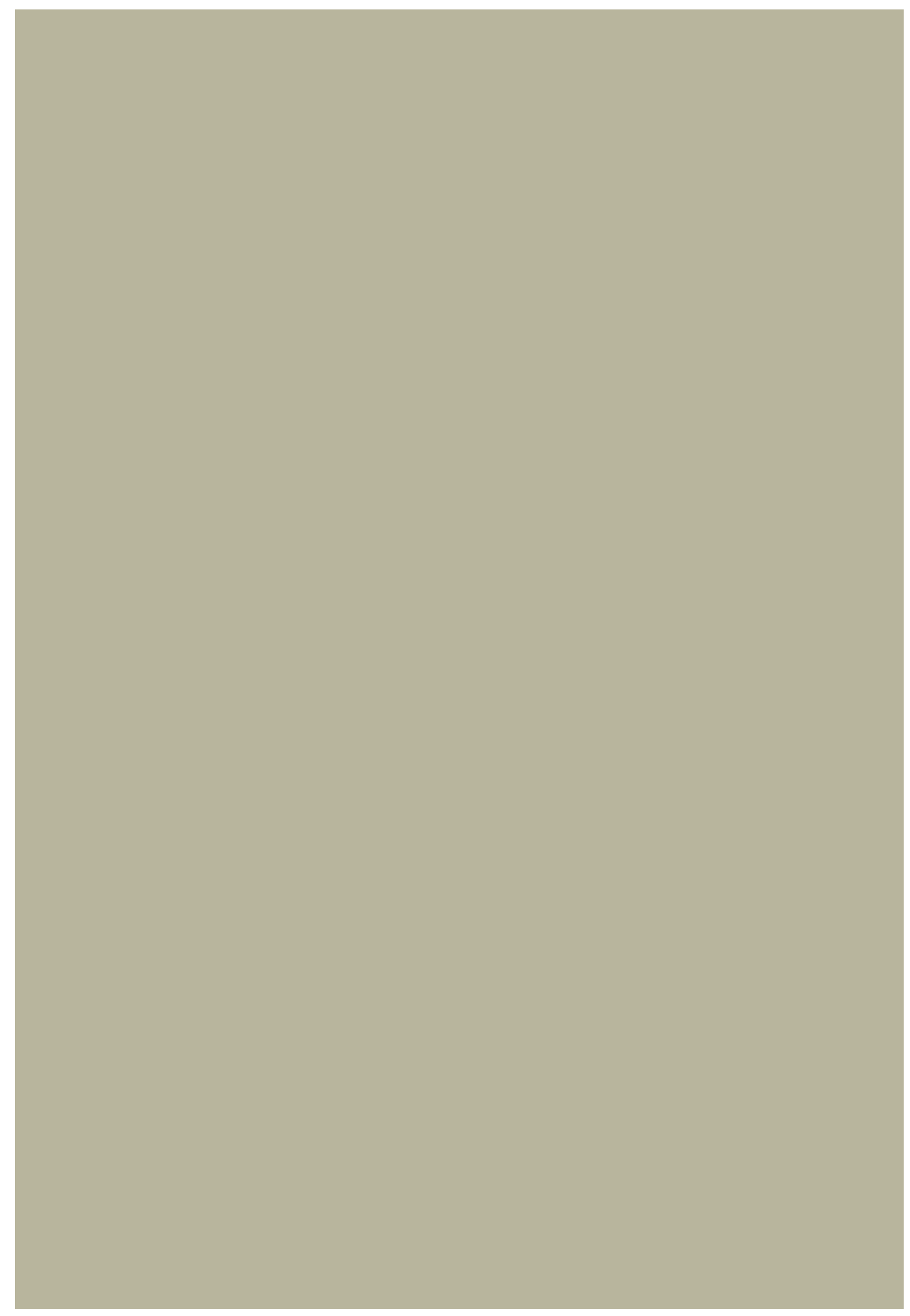

Fig. 4.. Altar in the Karksi Peetri church. (TÜR, F 192, A-25-16.). 
beauty"92. There is a narrow painting of the Last Supper in the predella of the central section of the altar, which is a direct invitation to Holy Communion, in which, according to the Lutheran Church, Jesus Christ also participated. The pulpit was above the Communion table. It has not survived, but it was probably a polygonal cantilevered pulpit with Rococo ornamentation on its panels.

Sten Karling attributed the altar in the Karksi Church to Carl Gottlieb Appelbaum, ${ }^{93}$ a master born in Radeburg, Saxony, who came to Riga from Lübeck. Karling's attribution is based on a comparison with the altar in St. John's Church in Riga that has been identified as the work of Appelbaum.${ }^{94}$ Karling considered the Karksi altar to be even more similar to the one in St. Catherine's Church (also known as the Bikernieki Church) in Latvia, which was also built by Appelbaum (1766). Based thereon, he dated the altar in the Karksi Church to the period from 1760 to $1770 .{ }^{95}$ The altarpiece of St. Catherine's Church is also a altar pulpit, which was rebuilt around 1875. A hundred years later, in the 1970s, it was taken to the Rundāle Palace Museum, where the Rococo-style pulpit is still stored today. In the Karksi Church, there is also a wooden baptismal font executed in the same style. ${ }^{96}$

The Karksi church was provided with an integrated solution at the same time. The galleries constructed on the western wall of the hall are supported by columns with smooth stemmed capitals with a composite order. Pictures of the Twelve Apostles are painted on the church galleries, and the design as a whole is dominated by the luminosity of an antique temple. Churches from the Age of Enlightenment are antique temples, with bright light and placid colours. ${ }^{97}$

92 Laugier, An Essay on Architecture, 219-220: In the middle at the height of the architrave which separates the two orders of Architecture, one may place a glory, with various groups of angels flying in the air round about the shining center, wherein should be the triangle with the name of God. One may put all the sanctuary in marble, and gild all the sculpture of it. [---] An altar thus designed as I have described, would be a perfect beauty.

93 Karling, Holzschnitzerei und Tischlerkunt, 418.

94 Levina, The Heritage of Religious Architecture, 67; Paul Campe, "Astonpadsmitā gadusimtena baroka altāri Rīgas ev.-luteriskās baznīcās / Die Barockaltäre des 18. Jahrhunderts in den ev. Luth. Kirchen Rigas." Latvijas Ūniversitātes raksti / Architektūras Fakultātes serija; 1,4 (Riga : Latvju Kultūras, 1931) 298,299 . The general appearance of the galleries is similar to lower gallery of Riga's St. John's Church. 95 Karling, Holzschnitzerei und Tischlerkunt, 417. According to Campe, there was an altar pulpit in the Bikernieki church.

96 TÜR, F 192, A-25-20.

97 Nilsén, Focal Point, 255. 
The Karksi Church was built as a Halliste chapel of ease and, and between 1774 and 1806 was served by Christian Heinrich von Seeberg, the pastor in Halliste. ${ }^{98} \mathrm{He}$ had studied at the Universities of Jena and Leipzig. Seeberg dealt actively with church construction and schools for the peasantry, thereby being an active Enlightenment-era pastor.

\section{THE ALTAR PULPIT IN RÄPINA'S ST. MICHAEL'S CHURCH}

A stone church was built in Räpina at the end of the $18^{\text {th }}$ century to replace the older wooden church. In the $1793^{99}$ and $1796^{100}$ editions of Mellini's Atlas of Livonia, the church is located on the shore of the Võhandu River reservoir, that is, in its present location. It is generally agreed that the new structure was completed in $1785,{ }^{101}$ when the churchwarden Baron Johann Gustav von Loewenwolde and his wife (Agrippina) Johanna Carolina, nee Baroness Meyendorff von Uexküll, donated a silver baptismal font to the church. ${ }^{102}$

In 1815, Körber called the church beautiful, bright and spacious (in German schöne, helle und geräumig), but does not mention the year it was built. ${ }^{103}$ Pastor August Gottlieb Major, who assumed his position in 1796, started a new church register and during a church visitation, all the church's property was inventoried. There is a note in the heading of the visitation minutes saying that everything listed in the 1776 inventory still exists. There is a loose sheet of paper with torn edges in the volume, which apparently is the 1774 inventory list, because the aforementioned baptismal font is not included. Among the textile items, an "altar and pulpit cloth" has been added to the 1796 list. ${ }^{104}$ Usually the altar and pulpit cloths were listed as separate items, but in Räpina, they formed a set, which was listed together throughout the $19^{\text {th }}$ century. So, it

\footnotetext{
98 EAA, 1276-1- 67, 11.

99 EAA, 854-4- 470; http://ais.ra.ee/index.php?tyyp=2\&module=202\&op=21\&leidandmed=E AA.854.4.470 (viewed 21.08.2014)

100 EAA, 2059-1-1464; http://ais.ra.ee/index.php?tyyp=2\&module=202\&op=21\&leidandmed=E AA.2059.1.1464 (viewed 21.08.2014)

101 Saarman. Pudemeid Räpina koguduse ajaloost, 9.

102 Kaalu Kirme, Kirikuhõbe uusajast tänapäevani. Eesti kirikute sisustus III (Tallinn: Muinsuskaitseamet, 2012), 85, 145.

103 EAA, 1269-1-530, 1.

104 EAA, 1269- 3- 3, 1, 5.
} 
Fig. 5. Sounding board in the altar of the Räpina Miikaeli church. Photo by Reet Pius.

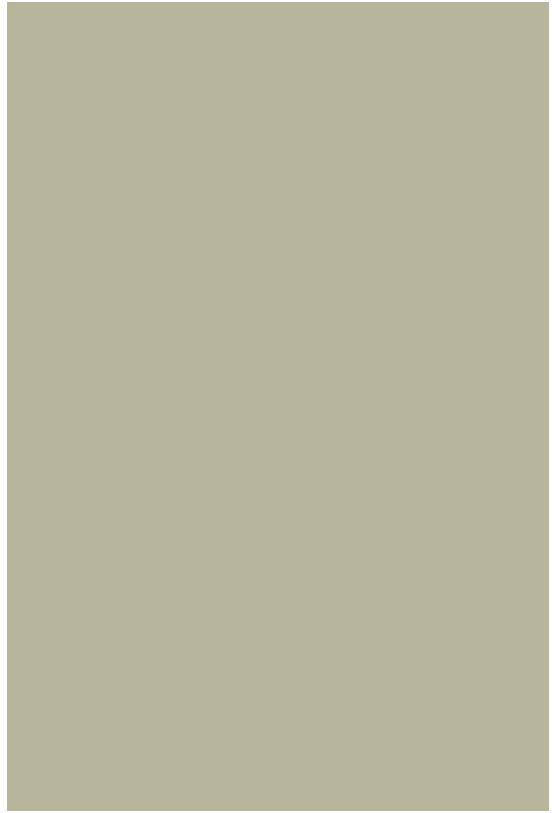

Fig. 6. Altarpiece in the Räpina Miikaeli church. Photo by Reet Pius.

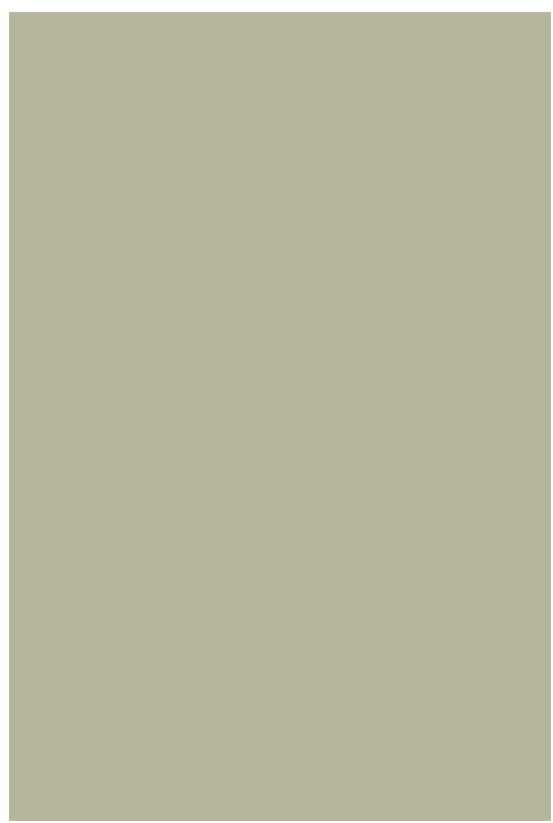

Fig. 7. Exterior view of the Räpina Miikaeli church. Photo by Sille Sombri. 
can be presumed that the new stone church really was built in 1785 and the altar pulpit was part of the concept for the church's construction. ${ }^{105}$

In the Räpina church, the organ gallery is above the altar pulpit, which conforms to Joseph Furttenbach's ideas about Lutheran church construction. Among Johann Wilhelm Krause's drawings, there is one that is dated 1796 of an unidentified village church, in which we can see a altar pulpit with a choir gallery attached to it. ${ }^{106}$ Krause varies the altar pulpits on different drawings and they are more flights of fancy than actual churches. ${ }^{107}$ The image depicted by Krause resembles the interior of the Räpina church, which alludes to the fact that the design of the Räpina portal altar pulpit was popular. The church building shares features with the Võru and Suntaži churches, which are called "twins" and associated with Haberland's structures. ${ }^{108}$ However, in the case of the Catherine's Church in Võru, the participation of Haberland is conjectural. ${ }^{109}$

Located in the eastern section of the hallchurch, the altar pulpit was framed by columns and setback pilasters. The entablature of the altar's columns that are designed like a temple portal are strongly profiled with prominent curves, thereby forming a sounding board for the pulpit, which is still above the altar. The Corinthian capitals of the altar columns are gilded.

In 1872, the congregation commissioned a new altarpiece from the artist Carl Antropoff. A horizontal picture of the entombment of Christ and a large vertical picture of the manifestation of Christ to Mary Magdalene are both in the same frame. Until the purchase of Antropoff's painting, there were no paintings listed in the church inventory, although the altarpieces were seldom included in the earlier inventory lists. It is possible that the picture depicting the entombment of Christ was com-

105 Saarman, Pudemeid Räpina koguduse ajaloost, 9.

106 Spārītis, "Kirchenbau - vom Rigaer Dom bus zum Jungfernhof”, 251, 263.

107 Krause made undated drawings of churches for Christmas, they served as the architect's Christmas cards.

108 Spārītis, "Klassizismus in der Sakralbaukunst Livlands", 73. Pastor Franz Bernhard Francke was from Riga (he served in Räpina from 1771 to 1796), and therefore, the involvement of master craftsmen from Riga would have been expected. For more about Franke, see E.H. Busch Beiträge zur Geschichte und Statistik des Kirchen- und Schulwesens der Ev.-Augsburg. Gemeinden im Königreich Polen / E. H. Busch. Ergänzungen der Materialen zur Geschichte und Statistik des Kirchen- und Schulwesens der Ev.-Luth. Gemeinden in Russland. 2 Bd. St Petersburg u Leipzig. http://www.digar.ee/id/nlib-digar:107417. (viewed 08.09.2014)

109 Campe, Lexikon liv-und kurländischer Baumeister, 324. 
missioned to replace another small-scale picture; this would explain the design of the altarpiece.

There are two niches on the sides of the western portal under the Räpina church tower containing the figures of Love and Hope. ${ }^{110}$ The wooden female figures, which are graceful in a way reminiscent of Canova's work but static, although they have always been painted white, giving them the appearance of marble. ${ }^{111}$

The extremely simple baptismal font decorated with beaded rope, the antique-style figures depicting the virtues, and the powerful columns of the altar pulpit are testimony to the aesthetic aspirations described by Abbé Laugier, which elevated the churchgoers who came from smoky peasant houses into human beings. ${ }^{112}$

\section{THE ALTAR PULPIT IN VALGA'S ST. JOHN CHURCH}

The story of the construction of the Valga church starts in 1779 when the town council decided to build a new church and applied to the Livonian provincial government in Riga for a permit. ${ }^{113}$ The church's construction is well documented and, in the context of Livonia, the building itself is exceptionally beautiful and has therefore attracted the interest of historians. The letter included with the permit from the Livonian provincial government, which is signed by Governor General George Browne, Deputy Governor Balthasar von Campenhausen and Landrat Otto Hermann von Vietinghoff, ${ }_{114}^{114}$ notes that the "future church must truly become a jewel

110 Külli Erikson identified them as Love and Hope, and considered the door between them to be the symbol of faith. http://register.muinas.ee/?menuID=monument\&action=view\&id=5242 (viewed 21.08.2014). The female figure on the left lacks attributes by her hand being placed on her breast also means faith and alludes to the pietist motto: "God lives in the heart." Haebler, Das Bild in der evangelischen Kirche, 68.

111 Estonian National Heritage Board (hereinafter EMA), Toimik 4-8/ 6 I kd. Objects EMA 5241; EMA, 5242.

112 At the end of the $18^{\text {th }}$ century, the peasants in Estonia and Livonia were treated as slaves, and thought to be filthy and stupid.

113 EAA, 1299-1-98, 1-2; Jaak Viires, Valga linn, Jaani kiriku ehituslugu. Ajalooline õiend (Tallinn, 1991, manuscript in the archives of the National Heritage Board [MKA], ERA, T-76, 1, 13063), 6.

114 Paul Campe, Otto Hermann v Vietinghoff gen Scheel, Marienburg der sogenannte "Halbkönig v. Livland. Baltische Hefte. (Hirschheyd, 1960). Otto Hermann v Vietinghoff gen Scheel (1722-1792) was privy counselor of the Russian Empire and the father of Barbara von Krüdener (see footnote 28); at the end of the $18^{\text {th }}$ century, his son Burchard Christof von Vietinghof (1767-1828) donated highquality copies of paintings by famous masters to the Alūksne church. The works that were copied included Giovanni Lanfranco (1581-1647) Madonna, Carlo Cignani (1628-1719) Maria Magdalena, Pellegrino Tibaldi (1527-1591) Angel, Palma Vecchio (1480-1528) The Entombment of Christ, and Anton van Dyck`s (1599-1641) The Entombment. See Mašnovskis, Latvijas luterānnu baznīcas, I, 49-51. 


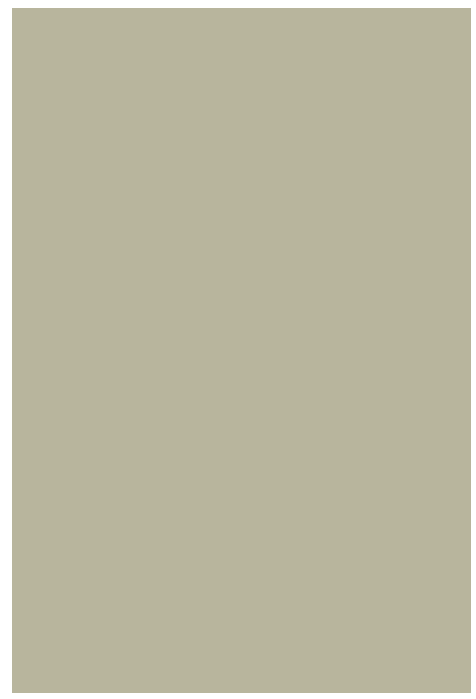

Fig. 8. Exterior view of the Valga Jaani church. Photo by Kaire Tooming.

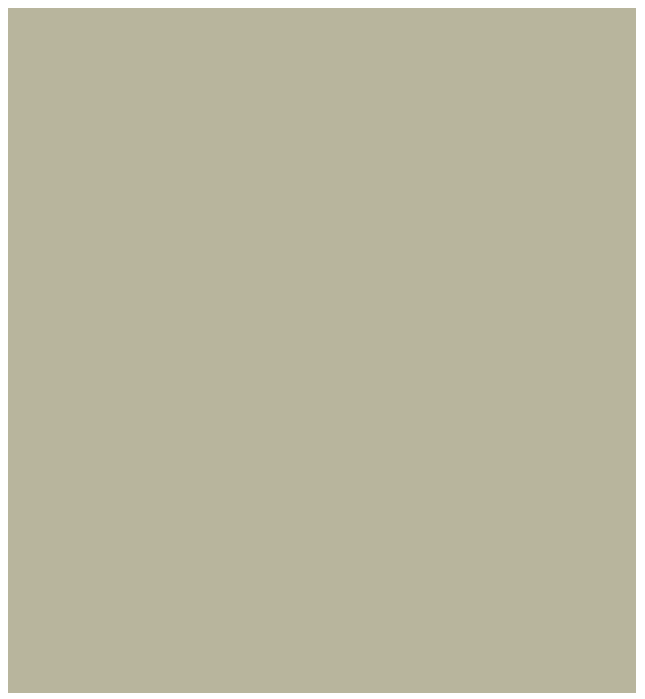

Fig. 9. Capital of the altarpiece in the Valga Jaani church. Photo by Reet Pius.

of the city and be proof to subsequent generations of the skilful use of church resources".115 In the course of a correspondence that lasted for years, the provincial government suggested that Cristoph Haberland, the Riga city architect, be the builder, and his plans were reviewed in 1787. ${ }^{116}$ Haberland, who became the Riga city architect in $1789,{ }^{117}$ was known outside of the Livonian capital as an innovative church architect. The Baltic-Germans Heinz Pirang ${ }^{118}$ and Ottokar Gerich ${ }^{119}$ have written about Haberland's life and work, and Juri Vassiljev's monograph on Riga Classicism includes a chapter on him. ${ }^{120}$ Unlike the first two authors, Villis Purvitis, a Latvian art historian, believes that Haberland may have been in contact with architect Friedrich August Krubsacius (1718-1790)

115 Viires, Valga linn, Jaani kiriku ehituslugu, 7; EAA, 1299-1-98, 11-2. „Wie nur das Keiserliche General Gouverment dieses zur Ehre Gottes gereichende Werk, welches zugleich eine zierde der Stadt, so wie für die Nachkommen ein redenker Beweis won der guten Verwaltung der Kirchen-Mittel seyn wird, hierdurch obrigkeitlich genehmiget unter dessen Protection nimmt. [---] Riga-Schloss den 13ten Decembris 1779." In the building arts, rationalism is one of the keywords in $18^{\text {th }}$ century architecture, see Honour, Neo-classicism, 122.

116 Viires, Valga linn, Jaani kiriku ehituslugu, 1 8; EAA, 1299-1- 97, 114-15.

117 Pirang, „Christoph Haberland”, 11.

118 Ibid., 3-23.

119 Ottokar Gerich, Christoph Haberland und seine Bauten, (Berlin, 1928).

120 Васильев, Классииизм в архитектуре Риги, 148-171. 
Fig. 10. Altarpiece in the Valga Jaani church. Photo by Sille Sombri.

Fig. 11. The Last Supper after Leonardo da Vinci. Panel of the altarpiece in the Valga Jaani church. Photo by Reet Pius. 
during his study trips to Dresden. ${ }^{121}$ Based on Haberland's work, it can be concluded that besides being familiar with Krubsacius's structures, he had also read his translation of Laugier's architectural handbook, since, as a newly published work, it must have been very topical among architects during one of Haberland's study trip. ${ }^{122}$

The new idiom of form is related to integrated functional solutions, of which the synthesis of the sacristy with the general layout of the church building should be emphasised. St. John's Church in Valga seems to be oval, but is actually an elongated octahedron, in which the sacristy is shaped like a rotunda resembling an antique temple. The pulpit is placed within the temple portico. ${ }^{123}$ The altar pulpit was actually built, but it was rejected by the congregation and was later walled up. ${ }^{124}$ Pirang believes this was happened quite soon after the construction, which is believable, because the door leading to the pulpit is walled up using the same bricks used to building the sacristy. ${ }^{125}$ The church was not consecrated until $1816,{ }^{126}$ and therefore the painting of the Last Supper after Leonardo da Vinci probably also dates from that era ${ }^{127}$ along with the decorations of the altar pulpit's Communion table. The large altarpiece called Resurrection of Christ seems to date from the mid- $19^{\text {th }}$ century.

As recommended by Laugier, Haberland placed the altar on the end wall of the church, thereby letting the light flow into the space. The placement of the altar was based on Sturm's guidelines ${ }^{128}$ as well as Laugier's aesthetics.

121 Viires. Valga linn, Jaani kiriku ehituslugu,19; Васильев, Классицизм в архитектуре Риги, 150.

122 Marc-Antoine Laugier, Des Abbts Laugier neue Anmerkungen über die Baukunst nebst einem zweifachen Anhange, als des Herrn le Roi Geschichte der Einrichtung und Gestalt der christlichen Kirchen von Kaiser Constantin dem Grossen bis auf unsre Zeit; und ein Vorschlag zu einem Komödienhause (Leipzig: M. G. Weidmanns Erben und Reich, 1768). Haberland went on a study trip to Dresden where Krubsacius was active when the book had just been published.

123 Pirang, „Christoph Haberland”, 11, 18.

124 The portal of the pulpit-altar is visible on the ceiling of the sacristy.

125 Pirang, „Christoph Haberland” 10-11; Viires, Valga linn, Jaani kiriku ehituslugu, 23.

126 Bruno Ederma, Asta Jaik, Eesti Evangeeliumi Luteriusu kirikud (Tartu: K. Jaik, 1939), 108.

127 Kreem, „Maalikoopiad Eesti evangeelses luterlikus kirikus 19. Sajandil“, 46; http://register. muinas.ee/?menuID=monument\&action=view\&id=16486, (viewed 21.08.2014). The painting in the Lääne-Nigula church (Läänemaa), which is a copy of Leonardo da Vinci's The Last Supper, is dated 1814 , and is earliest known copy of da Vinci's work in an Estonian church.

128 Spārītis, „Klassizismus in der Sakralbaukunst Livlands”, 78. 


\section{IN CONCLUSION}

Altar pulpits appeared in Estonian church interiors in the final quarter of the $18^{\text {th }}$ century in the churches that were built at that time, and were part of an integrated solution for church construction. In the churches that were built in Northern Livonia in the last quarter of the $18^{\text {th }}$ century, which have been examined here, the building of the altar pulpits has been associated with the names of famous Riga masters, who were educated in Germany.

The founders of these churches were inspired by a desire to erect buildings that would embellish their locations and all these churches have garnered recognition from their contemporaries. Based on the example of the Valga church, we know that the leading role in determining the appearance of the church was played, not by the Valga town council, but by the churchwarden and Livonian provincial government. The construction of architectonic altar pulpits reflected the knowledge of the church founders regarding "perfect beauty" with the clear goal of emphasising elitist concepts of contemporary architecture. The columns of the portico altars symbolise a house of God and the pulpit between the columns a preaching-church. The decorations of the Communion table were modest, its meaning in the sharing of the Sacrament of Communion was emphasised by its small-scale, horizontal format that recalled the Last Supper.

Although the German architectural theoretician Leonhard Christoph Sturm held pietist views, his functional church plans have been used by various confessions of faith. The theory of "good architecture" proffered by Marc-Antoine Laugier, a French Catholic priest and architectural theoretician, suited the Lutheran Church's principles of congregational churches and Enlightenment-era churches as meeting rooms for the congregation.

In Estonia during the $18^{\text {th }}$ century, the boundaries between various confessional movements were blurred. The pastors of the churches examined above were not publicly associated with Pietism, although, through Sturm's architectural books, pietist functionalism left its mark on the churches built in $18^{\text {th }}$-century Livonia. 
Reet Pius: The Altar Pulpit in Estonian Church Interiors Keymords: Pulpit-Altar, Church Construction, Lutheranism, Pietism, Rationalism, Second Half of the 18 Th Century

SUMMARY:

The article focuses on a phenomenon that is related to architecture and art history in Estonia in the late 18th century - the pulpit-altar. In Estonia and Livonia, the construction of pulpit-altars was associated with the building of new stone churches.

Although, due to the scarcity of sources, it is not possible to get a total overview of the spread of the pulpit-altars, the architectonic portico-style pulpit-altars are most prevalent in Livonia and primarily associated with the work of Carl Gottlieb and Christoph Haberland, two masters who were active in Riga. The portico-style pulpit-altars combined the functionality of the church plans designed by L. Chr. Sturm, a German educator and architect, and the aesthetics of "good architecture" promoted by architectural theoretician Marc-Antoine Laugier.

In Estonia and Livonia, which had come under the rule of Tsarist Russia, Swedish church law remained in effect until 1832, although along with orthodox Lutheranism, Pietism, Herrnhutism and Rationalism were tolerated here. The goal of the Pietists, Herrnhutists and Rationalists was to improve the economic and social conditions in Estonia and, in one way or another, they were all enlighteners. Church construction may also have been influenced by the educational background of the pastors, as well as the religious and aesthetic preferences of the church authorities. It is difficult to determine the dominance of one or another theological movement. The rural church buildings of the Age of Enlightenment were meeting rooms that were open to people of any social status or Lutheran sect.

The pulpit-altars in the churches in Karksi, Räpina and Valga are covered in the article.

\section{CV:}

Reet Pius is PhD candidate at the University of Tartu, Graduated from the University of Tartu and the Central European University. Worked at the KANUT Conservation Centre as an art historian and at the Art Museum of Estonia as a research secretary, and also curated exhibitions at the Art Museum of Estonia. Co-author of the exploratory survey, Eesti 
kunsti ajalugu 2, 1520-1770, 2005 (The History of Estonian Art 1520-1770). Current research topic is "The Lutheran Church and ecclesiastic art in Estonia during the Age of Enlightenment."

e-mail: reet.rast@mail.ee 